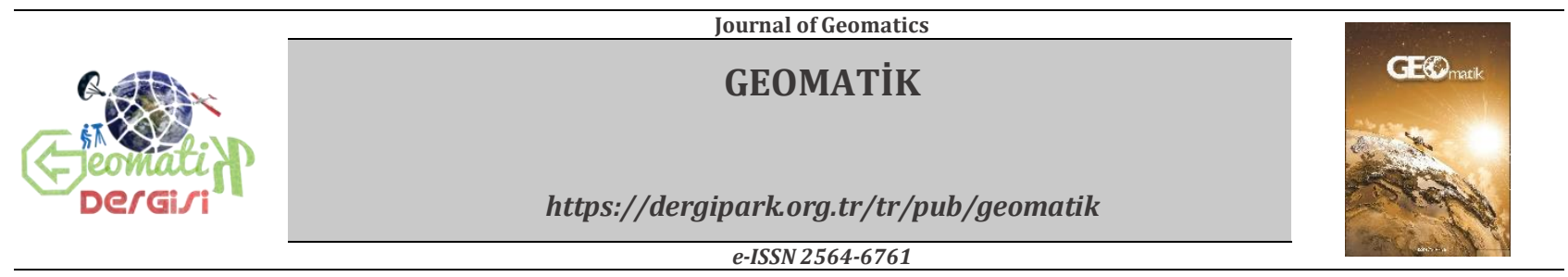

\title{
Enerji nakil hattı projelerinin uygulanmasında arazi mülkiyetinin kazanılması sürecinin değerlendirilmesi
}

\author{
Fatih Döner*1( ${ }^{*}$, Erhan Kaya² \\ ${ }_{1}^{1}$ Gümüşhane Üniversitesi, Mühendislik ve Doğa Bilimleri Fakültesi, Harita Mühendisliği Bölümü, Gümüşhane, Türkiye \\ ${ }^{2}$ TEDAȘ, ARAS Bölge Müdürlüğ̈̈, Kamulaştırma Birimi, Erzurum, Türkiye
}

\author{
Anahtar Kelimeler \\ Enerji Nakil Hattı \\ Mülkiyet \\ Kadastro \\ Taşınmaz Değerleme
}

\begin{abstract}
ÖZ
ENH (Enerji Nakil Hattı) projeleri hazırlanırken başta ekonomik, çevresel ve güvenlik gibi konular dikkate alınarak ENH’nın geçirileceği araziler belirlenmektedir. ENH projelerinin hayata geçirilebilmesi belirlenen bu arazilerin mülkiyetinin kazanılması süreci sonrasında mümkün olmaktadır. Bu çalıșmada, ENH projelerinin uygulanmasında arazi mülkiyetinin kazanılması süreci değerlendirilmektedir. Veriler incelendiğinde, son bir yılda ENH ile ilgili açılan dava sayısının 15759 ve beş yıllık dönemde arazi malikleriyle mahkemesiz uzlaşma oranının \%13 olduğu görülmektedir. Dava sayısının fazla, uzlaşma oranının düşük olmasındaki en büyük etken ENH'nın geçirileceği arazi için ödenecek bedelin belirlenmesindeki taşınmaz değerleme çalışmalarıdır. Referans alınan değerleme yöntemleri, ölçütler ve oranlar sonucunda belirlenen arazi değeri çoğu durumda gerçek değeri yansıtmadığından arazi sahipleriyle uzlaşma sağlanamamaktadır. En ideal çözümün yasal boyutta, taşınmaz değerleme faaliyetlerini tek başına düzenleyen bütüncül bir değerleme yasasının hazırlanması, kurumsal boyutta kadastronun taşınmaz değerlemeyi de içermesi ve teknik boyutta güncel alım-satım değerleriyle birlikte taşınmaz özelliklerinin bir arada yönetilebileceği bir veri tabanının oluşturulması olduğu değerlendirilmektedir.
\end{abstract}

\section{Evaluation of the process for acquisition of land property in the implementation of power transmission line projects}

\section{Keywords}

Power Transmission Line

Property

Cadastre

Real Estate Valuation

\begin{abstract}
While preparing PTL (Power Transmission Line) projects, the land where the PTL is crossing is determined by considering criteria such as economy, environment and security. The realization of PTL projects is possible after acquisition of property of these lands. In this study, the process of acquisition land property in the implementation of PTL projects is evaluated. When data are examined, it is seen that the number of lawsuits filed against the PTL in past year was 15759 and rate of non-court settlement with land owners in the five-year period was $13 \%$. The main factor for the high number of lawsuits and low settlement rate is real estate valuation studies in determining the price to be paid for land to which the PTL will be established. As land value determined as a result of valuation methods, criteria and rates referenced does not reflect real value in most cases, no agreement can be reached with the land owners. It is considered that most ideal solution from a legal point of view is to prepare a holistic valuation law that regulates real estate valuation activities, from an organizational point of view is to set a connection between cadastre and real estate valuation and from a technical point of view is to set-up a database which enables managing properties of real estates and their up-to-date values.
\end{abstract}




\section{GíRiş}

Elektrik üretim tesisleri ile transformatör merkezleri ve son tüketici arasında elektrik enerjisi iletimini sağlayan sistemlere enerji nakil hatları (ENH) denir. Türkiye'nin gelişmekte olan bir ülke olması ve artan nüfusu nedeniyle elektrik ihtiyacı artmakta, bu ihtiyacı karşılamak için yeni üretim tesisleri ve ENH oluşturulmaktadır. Türkiye elektrik üretim istatistikleri (TEİAŞ, 2020a) incelendiğinde 2000 yllında 125 teravatsaat (TWh) olan yıllık elektrik üretiminin 2019 yılı için 291 TWh olduğu görülmektedir (Şekil 1). Elektrik üretimindeki bu artışla birlikte, hem yer üstü hem de yer altı iletim hattı uzunluğu da yıllar içinde artış göstermiştir (TEİAŞ, 2020b). 2000 yılında Türkiye'deki yer üstü toplam iletim hat uzunluğu $41202 \mathrm{~km}$ iken bu değer 2018 yılında 68203 km'ye çıkmıştır (Şekil 2). Türkiye'nin 2000 yılında $100 \mathrm{~km}$ olan toplam yer altı iletim hattı uzunluğu ise 2018 yılına gelindiğinde 554 km'ye ulaşmıştır.

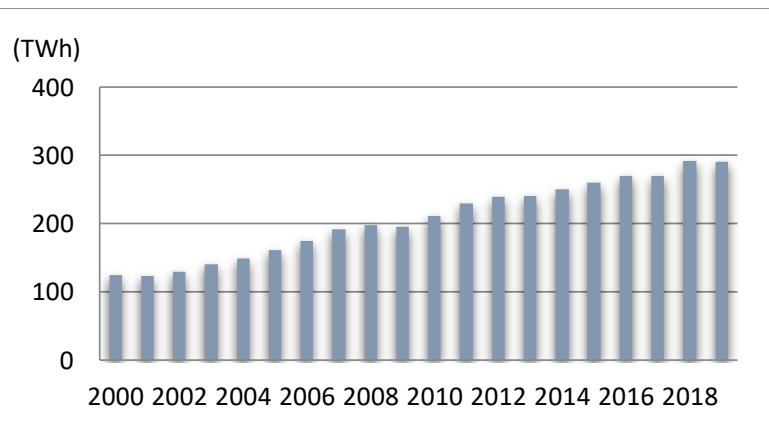

Şekil 1. Türkiye'de yıllara göre TWh biriminde elektrik enerjisi üretimi

Türkiye'de üretilen elektrik enerjisinin son kullanıcıya ulaştırılmasında üç aşamalı bir kurumsal yapılanma bulunmaktadır. Elektrik enerjisi üretim faaliyeti kamu ve özel şirketler tarafından gerçekleştirilir. Elektrik Üretim Anonim Şirketi (EÜAŞ), kamuya ait elektrik santrallerindeki üretimden sorumludur. Elektrik santrallerinde (termik, hidroelektrik, doğalgaz, jeotermal, güneş ve rüzgâr) üretilen elektrik enerjisi yüksek gerilim hatlarıyla transformatör merkezlerine iletilir. Bu iletim faaliyetinden Türkiye Elektrik İletim Anonim Şirketi (TEİAŞ) sorumludur. Orta ve düşük gerilim hatları vasıtasıyla elektrik enerjisinin yerleşim yerlerine dağıtılması ise dağıtım şirketlerinin sorumluluğundadır. Türkiye genelinde 21 farklı bölgede faaliyet gösteren dağıtım şirketlerinin denetiminden Türkiye Elektrik Dağıtım Anonim Şirketi (TEDAŞ) sorumludur (Şekil 3).

ENH projeleri hazırlanırken bașta ekonomik, çevresel ve güvenlik gibi konular dikkate alınarak ENH'nın geçirileceği araziler belirlenmektedir. ENH projelerinin hayata geçirilebilmesi, belirlenen bu arazilerin mülkiyetinin kazanılması (veya mülkiyetin edinimi) süreci sonrasında mümkün olmaktadır. Türkiye'de kamu yararı için arazi mülkiyetinin kazanılmasında temel yasal dayanak
Medeni Kanun'dur (RG, 2001). Bununla birlikte, Kamulaştırma Kanunu'na göre ENH'dan etkilenecek her bir parsel için ödenecek bedel belirlenmektedir. Kamulaştırma (ya da irtifak) bedeli, ENH'nı tesis edecek kurum bünyesinde oluşturulan bir kıymet takdir komisyonu tarafından belirlenmektedir. Kurumların kendi bünyesinde oluşturdukları bu komisyon marifetiyle belirledikleri kamulaştırma bedeli çoğu durumda gerçek değeri yansıtmadığından taşınmaz sahipleriyle anlaşma sağlanamamaktadır. TEDAŞ tarafından 2013-2018 yılları arasında gerçekleştirilen ENH kamulaştırma çalışmalarında maliklerle uzlaşma oranı \%13 olarak gerçekleşmiştir. Bunun yanında, TEDAŞ verilerine göre 2018 yılında kamulaştırmasız el atma ve bedel tespitiyle ilgili olarak açllan toplam dava sayısı 15759 olmuştur (TEDAŞ, 2018). Bu durum, hukuki ve sosyal problemleri beraberinde getirmekte aynı zamanda gelecekteki ENH kamulaştırma çalışmaları için de emsal değerlerin yükselmesi, taşınmaz sahiplerinin beklentilerinin artması, uzlaşma oranlarının düşmesi gibi sonuçlar doğurabilmektedir.

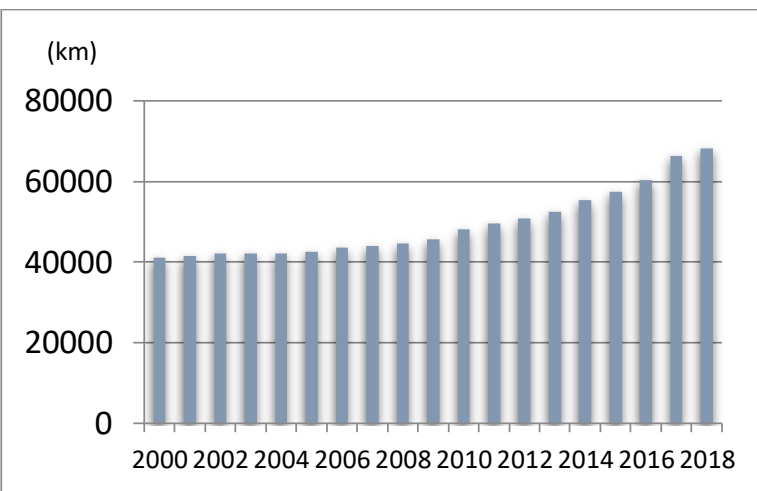

Şekil 2. Türkiye yer üstü iletim hat uzunluklarının km biriminde yıllık gelişimi
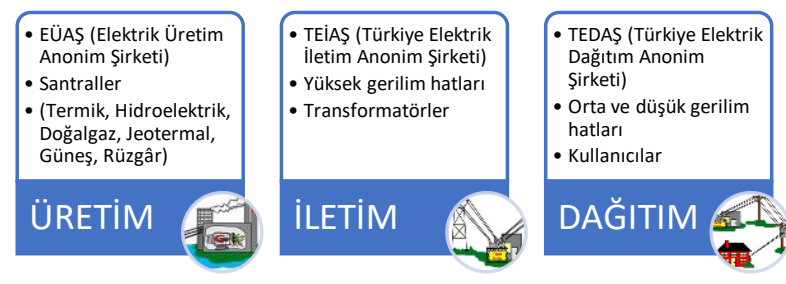

Şekil 3. Türkiye'de elektrik enerjisinin üretimi, iletimi ve dağıtımındaki kurumsal yapı

Türkiye'de ENH güzergâhlarının belirlenmesiyle ilgili bazı teknik çalışmalar yapılmıştır. Başlak (2013)'te Coğrafi Bilgi Sistemleri (CBS) ve Çok Kriterli Karar Verme Tekniği ile ENH için optimum güzergâh belirleme gerçekleştirilmiştir. Eroğlu (2014)'de CBS destekli bir model, en uygun ENH güzergâhının belirlenmesi için kullanılmıştır. Yıldırım vd. (2016)'da bir ENH güzergâhının çevreye olan etkisini en aza indirmek için CBS destekli bir güzergâh belirleme modeli önerilmiștir. Güzergâh belirleme çalıșmaları yanında Bayındır (2018)'te ENH 
kamulaştırmalarında değer tespitinde karşılan sorunlar incelenmiștir. Marabaoğlu ve Uzun (2019)'da ENH'nın tașınmazların değeri üzerindeki etkileri araștırılmıștır. Bunlar yanında, ENH'dan bağımsız olarak literatürde kamulaştırma (Çelik ve Baz, 2019; Ünel ve Yalpır, 2019; Çağla vd., 2016) ve taşınmaz değerleme (Şenyıldız 2017; Erdem, 2019; Tanrıvermiş ve Aliefendioğlu, 2019) ile ilgili olarak çok sayıda çalışma bulunmaktadır.

Mevcut çalışmalar dikkate alındığında, bunların ENH projelerinin ya sadece teknik ya da sadece yasal konularını ele aldıkları görülmektedir. $\mathrm{Bu}$ nedenle, bu çalışmada ENH projelerinin uygulanmasında arazi mülkiyetinin kazanılması süreci teknik ve yasal boyutlarıyla bir arada ele alınmaktadır. İkinci bölümünde çalıșmada kullanılan materyal ve yöntem tanıtılmaktadır. Üçüncü bölümde ENH geçişi nedeniyle kamulaştırılacak parsellerin ve parsel kamulaştırma alanlarının belirlenmesindeki teknik hazırlık aşamaları değerlendirilmektedir. Dördüncü bölümde ENH projelerinin uygulanabilmesi için gerçekleştirilen hukuki işlemler kamulaştırma ve taşınmaz değerleme başlıkları altında incelenmektedir. Beșinci bölümde bulgular ve tartışma yer almaktadır. Çalıșma sonuç bölümüyle sona ermektedir.

\section{MATERYAL VE YÖNTEM}

Bu çalışmada, materyal olarak seçilen bir ENH projesi kullanılmıştır. Bu proje ile ilgili teknik çalışmalar, kamulaştırma ve taşınmaz değerleme faaliyetleri çalışmanın sonraki bölümlerinde incelenmiştir. Böylece mevcut mevzuat, literatür ve seçilen projenin uygulanmasıyla elde edilen verinin incelenmesine dayalı bir yöntem izlenmiştir. Seçilen örnek ENH projesi, Bayburt ili Merkez ilçe Söğütlü ve Sancaktepe köylerinden geçmekte olup 4069.04 m uzunluğundadır. Proje ayrıca 26 direk (pilon) yeri içerecek şekilde planlanmıştır. Proje sahasında, özel mülkiyete konu tarım arazisi niteliğinde 22 parsel, devletin hüküm ve tasarrufu altında bulunan taşlık ve dere cinsinde 11 parsel, tarla cinsinde hazine arazisi niteliğinde 8 parsel ve köy tüzel kişiliği adına kayıtlı yol cinsinde 4 adet parsel olmak üzere toplam 45 parsel bulunmaktadır. $\mathrm{Bu}$ parsellerin toplam büyüklüğü 468431.,83 metrekaredir.

Ön inceleme çalışmasıyla proje bölgesinin temel nitelikleri belirlenmeye çalışılmıştır. Buna göre, ENH tesis edilecek bölgeye genel olarak ulaşım sorunu bulunmamaktadır. Bölgedeki taşınmazların tamamı tarım arazi niteliğinde olup tapu kayıtlarında taşınmaz cinsleri tarla olarak belirtilmektedir. Bazı tarım arazilerinde birkaç yıldır tarım yapılmadığı belirlenmiștir. Bunun yanında, proje kapsamındaki taşınmazların tamamına yakını hisselidir. Bazı taşınmazların tapu kaydında ipotek, haciz gibi kisitlamalar bulunmaktadır. Nüfus yoğunluğu çok düşük olan köylerde, yaşayan halkın gelir durumu orta seviyededir. Proje bölgesinde, taşınmazların alım satımına yönelik bir pazar oluşmamıştır. Bu nedenle taşınmazlar için alım-satım kolaylığı bulunmamaktadır. Taşınmazların yakınında akaryakıt istasyonları ve akaryakıt temin edilebilecek tarım kooperatifleri mevcuttur. Bölgede yetiştirilen meyve ve sebze ürünleri açısından çeşitlilik vardır. ENH güzergâhının geçtiği bölgede orman alanı bulunmamakta olup kadastro çalışmaları tamamlanmıştır. Şekil 4'te, Söğütlü Sancaktepe ENH güzergâh planı köy sınırıyla birlikte gösterilmektedir.

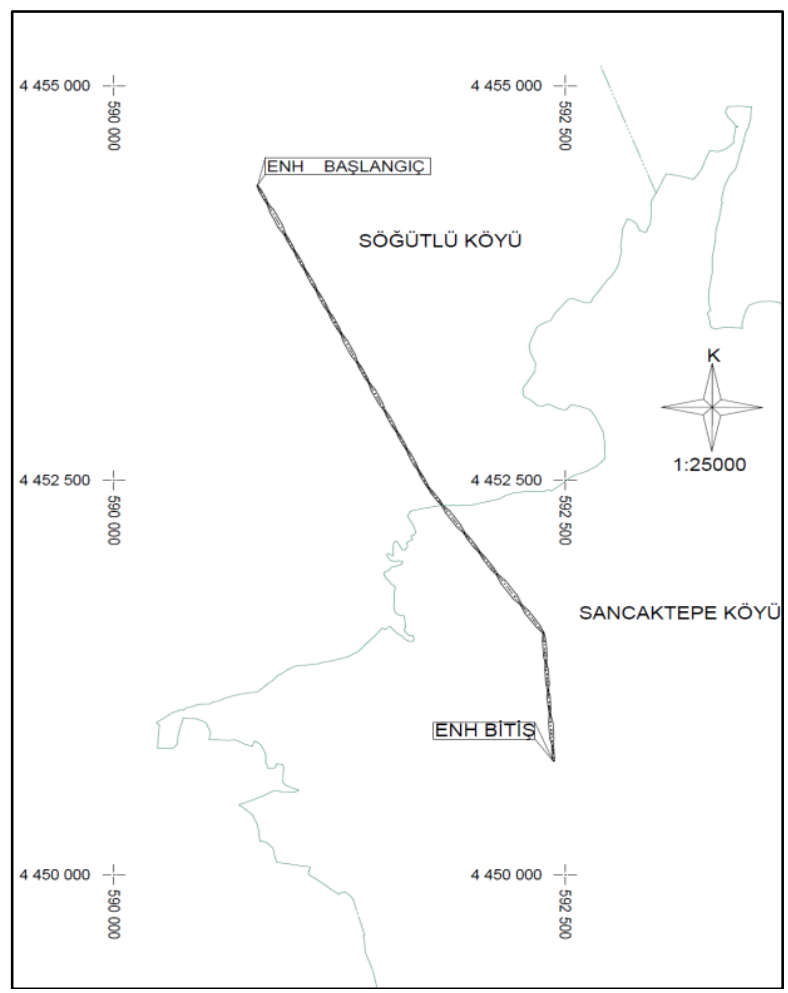

Şekil 4. Söğütlü ve Sancaktepe ENH güzergâh planı

Calıșma kapsamında ENH projesinin uygulanmasındaki süreç Şekil 5'deki gibi parçalara ayrılarak ele alınacaktır. Bu sayede, hazırlık çalışmaları, kamulaştırma ve taşınmaz değerleme faaliyetleri kendi içerisinde sürecin bir parçası olarak değerlendirilebilecektir.

\section{ENH PROJELERININ UYGULANMASINDA HAZIRLIK ÇALIŞMALARI}

Hazırlık çalışmaları ön arazi etüdü ile gerçekleștirilen ölçme/haritalama faaliyetlerini, ilgili kurumlardan proje alanına ilişkin bilgi/belgelerin teminini, toplanan bu bilgiler kullanılarak hazırlanan profil projesinin (elektrik projesi) üretimini, ilgili teknik mevzuata göre $\mathrm{ENH}$ için kamulaştırma/irtifak yüzölçümlerinin hesaplanmasını ve kamulaştırma planının hazırlanmasını kapsamaktadır. Şekil 6'da örnek olarak seçilen Söğütlü-Sancaktepe ENH projesi kamulaştırma planının bir bölümü gösterilmektedir. 


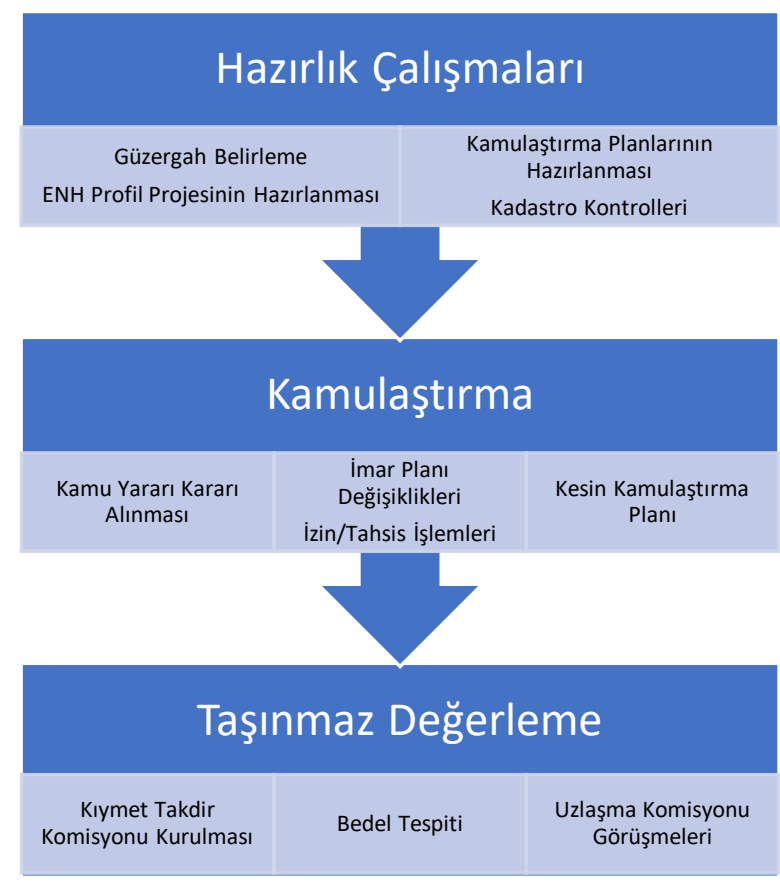

Şekil 5. Çalışma için belirlenen ENH projelerinin uygulanmasındaki süreç aşamaları

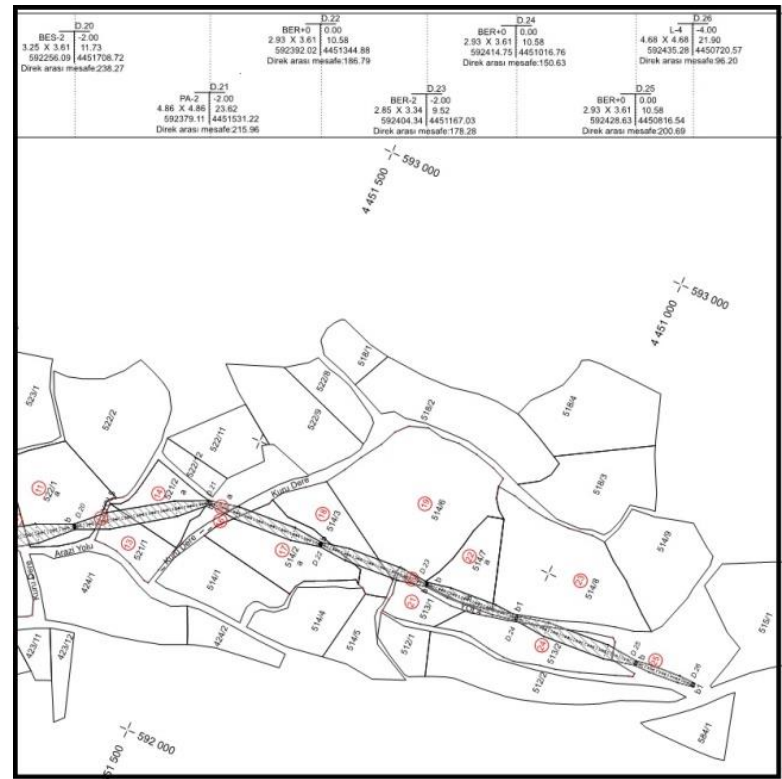

Şekil 6. ENH kamulaştırma planının bir bölümü

Arazide Büyük Ölçekli Harita ve Harita Bilgileri Üretim Yönetmeliği esas alınarak geçekleștirilen ölçme çalışmalarında günümüzde yaygın olarak GNSS (Global Navigation Satellite Systems-Küresel Seyrüsefer Uydu Sistemleri) tekniği kullanılmaktadır. Sögütlü-Sancaktepe ENH projesi ölçme işlerinde çift frekanslı GNSS alıcıları ile TUSAGA-Aktif (Türkiye Ulusal Sabit GNSS Ağı-Aktif Gerçek Zamanlı Kinematik hizmet veren GNSS Ağı-) sisteminde konum belirlenmiștir. Kadastro Müdürlüğ̈̈'nden temin edilen kadastro haritaları ITRF (International Terrestrial Reference FrameUluslararası Yersel Referans Çerçevesi) esas alınarak üretildiği için GNSS tekniği ile üretilen ITRF96 harita bilgileri ITRF'e dönüștürülmüsstür. Dönüşüm işleminde Kadastro Müdürlüğü'nden temin edilen dönüşüm parametreleri kullanılmıştır. Harita mühendisliği faaliyet alanına giren bu çalıșmalar yanında, ENH için profil projesinin hazırlanarak Elektrik Kuvvetli Akım Tesisleri Yönetmeliği'ne göre iletken salınım değerleri ve yaklaşma mesafelerinin belirlenmesi elektrik mühendisinin sorumluluğundadır. Ölçme çalışmalarıyla üretilen veriler ve elektrik projesinden elde edilen veriler birlikte kullanılarak, ENH nedeniyle kadastro parsellerinin kamulaştırılacak veya irtifak hakkı tesis edilecek kısımlarının (yüzölçümlerinin) hesabı gerçekleştirilir. $\mathrm{Bu}$ hesap için, TEDAŞ Genel Müdürlüğü tarafından yayınlanan Direk Yeri İstimlâk ve İrtifak Alan Hesabı Tabloları kullanılır. Günümüzde yaygın olarak NetCAD yazılımı ile yapılan bu hesaplama işlemine ait bir örnek aşağıda verilmektedir. Bu örneğe göre, Sögütlü-Sancaktepe ENH projesi 25 ve 26. direkleri arasındaki irtifak alanı $723.46 \mathrm{~m}^{2}$ olarak belirlenmiştir. İrtifak alanı hesabında kullanılan değerlerin sembolleri, Şekil 7'de gösterilmektedir. ENH projesinin tamamı için kamulaştırma ve irtifak yüzölçümleri sırasıyla $307.82 \mathrm{~m}^{2}$ ve $67100.76 \mathrm{~m}^{2}$ olmuştur.

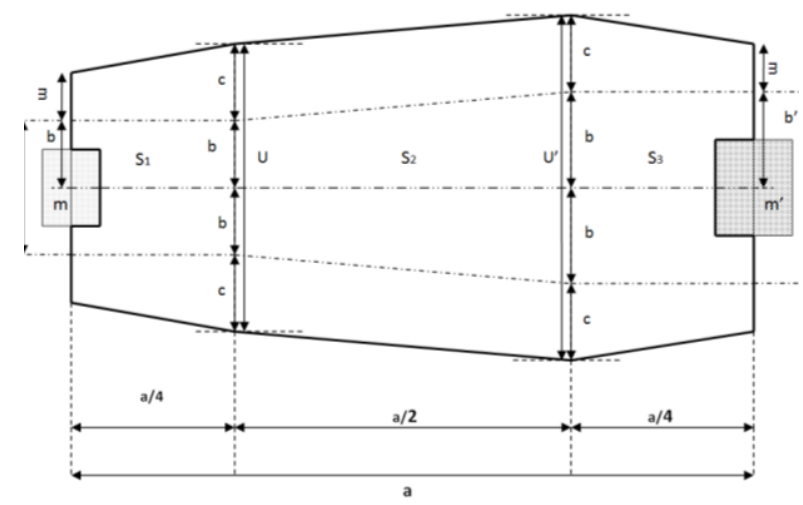

Şekil 7. İrtifak alanı hesabında kullanılan değerler

$\mathrm{m}=10.58 \mathrm{~m}^{2}$ (birinci direğin istimlâk alanıdirek tipine göre idare tarafından verilir)

$\mathrm{m}^{\prime}=21.9 \mathrm{~m} 2$ (ikinci direğin istimlâk alanıdirek tipine göre idare tarafından verilir)

$\mathrm{a}=96.21 \mathrm{~m}$ (iki direk arasındaki mesafe)

$\mathrm{t}=3.12 \mathrm{~m}$ (birinci direğin travers boyu-direk tiplerine göre idare tarafından verilir)

$\mathrm{t}^{\prime}=2.20 \mathrm{~m}$ (ikinci direğin travers boyu-direk tiplerine göre idare tarafindan verilir)

$\mathrm{b}=1.56 \mathrm{~m}$ (birinci direğin konsol boyu - $\mathrm{t} / 2$ )

$\mathrm{b}^{\prime}=1.10 \mathrm{~m}$ (ikinci direğin konsol boyu - $\mathrm{t}^{\prime} / 2$ )

$\mathrm{e}=2.0 \mathrm{~m}$ (emniyet mesafesi $-34.5 \mathrm{KV}$ ENH için)

$\mathrm{c}=2.684893 \mathrm{~m}$ (maksimum salınım-projeden alınır)

U: birinci direğe yakın irtifak hakkı sınırı genişliğini (m)

U': ikinci direğe yakın irtifak hakkı sınırı genişliğini (m)

S: toplam irtifak alanı

$U=2(b+c)=8.49 m$

$U^{\prime}=2\left(b^{\prime}+c\right)=7.57 m$ 
$\frac{(U+2(b+e))}{2} \frac{a}{4}-\frac{m}{2}=S 1=182.44 m^{2}$

$\frac{\left(U+U^{\prime}\right)}{2} \frac{a}{2}=S 2=386.27 \mathrm{~m}^{2}$

$\frac{\left(U^{\prime}+2\left(b^{\prime}+e\right)\right)}{2} \frac{a}{4}-\frac{m^{\prime}}{2}=S 3=154.65 m^{2}$

$S=(S 1+S 2+S 3)=723.36 m^{2}$

Kamulaştırma planı ENH tesisini gerçekleştirecek kurumun kendi personeli tarafindan hazırlanabileceği gibi ihale usulüyle özel sektöre de hazırlatılabilir. Kamulaștırma planıyla birlikte bir teknik rapor, direk tevzi listesi, direk orta noktalarının coğrafi ve UTM koordinatları, dönüşüm parametreleri, kamulaştırma ve irtifak köşe koordinatları, varsa orman alanları için ölçü krokileri, ENH'nın imar planı olan bölgeye isabet etmesi halinde isabet eden kısmın imar planı ve belediye meclis kararl, tescil bildirim beyannameleri, taşınmaz listeleri, taşınmazların cins ve malik bilgileri kontrol edilmek üzere Kadastro Müdürlügü'ne gönderilir. Kontrol ve onay gerçekleştikten sonra EHN projesi kamulaştırma süreci başlatılır.

\section{ENH PROJELERI IÇCiN HUKUKI IŞ̧ERIN YÜRÜTÜLMESI}

Bu bölümde, ENH projelerinin uygulanabilmesi için gerçekleştirilen hukuki işlemler kamulaştırma ve taşınmaz değerleme faaliyetleri başlıkları altında incelenmektedir.

\subsection{Kamulaştırma}

Taşınmaz mülkiyetinin sahibinin rızası aranmadan kamu yararı için bedeli ödenerek alınması olarak kısaca tanımlanabilecek kamulaştırma, kamu yararı kararı alınmasıyla başlamaktadır. ENH projeleri için kamu yararı kararı alınması ve onaylanması süreci kamulaştırmayı hangi idarenin gerçekleştireceğine bağlı olarak farklılıklar göstermektedir. TEİAŞ Yönetim Kurulu'nun aldığı kamu yararı kararı Enerji ve Tabii Kaynaklar Bakanı tarafından onaylanır. TEDAŞ tarafından gerçekleștirilecek ENH projeleri için, 30.03.2013 tarihinde yürürlüğe giren 6446 sayılı Elektrik Piyasası Kanunu'ndan önce başlatılan projelerde, kamu yararı kararı TEDAŞ Yönetim Kurulu tarafından alındıktan sonra Enerji ve Tabii Kaynaklar Bakanı tarafından onaylanmaktadır. 30.03.2013 tarihinden sonraki ENH projeleri için hem kamu yararı kararı alınması hem de onaylanması Enerji Piyasası Düzenleme Kurumu (EPDK) tarafından gerçekleştirilmektedir.

Sögütlü-Sancaktepe ENH projesi için EPDK tarafından kamu yararı kararı verildikten sonra özel mülkiyete konu taşınmazların tapu kayıtlarına şerh koyma işlemi gerçekleştirilir. Proje bölgesindeki tarım arazilerinin ENH tesisi için tarım dışı amaçla kullanılabilmesi, Toprak Koruma ve Arazi Kullanımı Kanunu'na göre Tarım Reformu Genel Müdürlüğü onayına bağlıdır. Onay sonrasında taşınmazların tarım dışı kullanımına izin verilen kısımları ifraz edilebilir. Bu çalışmada örnek olarak seçilen ENH güzergâhı imar planı dışındaki alanlardan geçmektedir. ENH'nın planlı alanlardan geçmesi durumunda kamu yararı kararı alınmasından sonra kamulaştırmayı yapan idarenin başvurusu ve ilgili Belediye Encümeni kararıyla plan tadilatı gerçekleştirilerek ENH güzergâhı imar planına ișlenir.

Özel mülkiyete konu taşınmazlar dişında, ENH'nın mera veya orman alanına isabet etmesi durumunda Tarım ve Orman Bakanlığı'ndan ilgili kanunlara göre izin talep edilir. Seçilen örnek projede 11 adet devletin hüküm ve tasarrufu altında bulunan taşlık ve dere cinsinde arazi, 8 adet tarla cinsinde Hazine arazisi ve 4 adet köy tüzel kişiliği adına kayıtlı tescil harici arazi olmak üzere toplam 23 taşınmaz bulunmaktadır. Tescil harici taşınmazların devir işlemleri Kamulaştırma Kanunu'nun 30.maddesine göre gerçekleştirilir. Bu göre, TEDAȘ'ın taşınmazların devri için başvurusuna muvafakat edilmez veya 60 gün içinde cevap verilmezse Danıştay ilgili dairesine başvurularak iki ay içinde verilecek kesin karara göre devir gerçekleşmektedir. ENH için devletin hüküm ve tasarrufu altındaki yerler ile hazine arazilerinin kamulaștırma veya irtifak işlemleri Elektrik Piyasası Kanunu ile düzenlenmiştir. Çevre ve Şehircilik Bakanlığı (ÇŞB) Milli Emlak Genel Müdürlüğü (MEGM) tarafından ilgili taşınmazlar için TEDAŞ lehine irtifak hakkı tesisi gerçekleştirilir. 10.07.2018 tarih ve 30474 sayll 1 numaralı Cumhurbaşkanlığı Kararnamesi ile daha önce Maliye Bakanlığı'na bağlı olan MEGM, ÇŞB'na bağlandığından işlemler ÇŞB tarafından yürütülür.

Gerekli izin/tahsis işlemleri sonrasında varsa proje alanıyla ilgili olarak diğer kurumların görüş ve önerileri dikkate alınarak kesin kamulaştırma planları hazırlanır. Görüldüğü gibi, ENH güzergâhının isabet ettiği arazinin mülkiyet durumuna göre kamulaştırma sürecinde farklı kurumlar yer almakta ve işlemler çeşitli kanunlar referans alınarak sürdürülmektedir (Şekil 8). Bu durum genel olarak kamulaştırma sürecini zorlaștırmaktadır. $\mathrm{Bu}$ noktada, kamulaștırma işlemini yürüten kurum personelinin bilgi ve tecrübesi ile kurumlar arası koordinasyon önem kazanmaktadır. Projenin uygulandığı bölgede bir kurum tarafından başlatılan kamulaştırma işlemleri devam ederken başka bir kurum tarafindan taşınmazların mülkiyet durumunu değiştirecek çalışmaların planlanması (örneğin arazi toplulaştırması) hukuki problemlere, zaman kaybına ve kamulaștırma maliyetinin artmasına neden olmaktadır. 


\subsection{Taşınmaz Değerleme}

Kamulaştırma için Türkiye'deki temel yasal dayanaklar Anayasa ve Kamulaştırma Kanunu'dur. Anayasa'nın 46.maddesinde, devlet ve kamu tüzel kişilerinin kamu yararının gerektirdiği hallerde, gerçek karşılıklarını peşin ödemek şartyyla, özel mülkiyette bulunan taşınmaz malların tamamını veya bir kısmını, kanunla gösterilen esas ve usullere göre kamulaştırmaya ve bunlar üzerinde idarî irtifaklar kurmaya yetkili oldukları ifade edilmektedir. 46.maddenin birinci fikrasında ödeme şeklinin peşin olarak ifade edilmesine karşın aynı maddenin ikinci fikrasında tarım reformunun uygulanması, büyük enerji projelerinin gerçekleștirilmesi, iskân ve turizm gibi amaçlarla kamulaştırılacak toprakların bedellerinin beş yılı aşmayacak şekilde eşit taksitlerle ödenebileceği belirtilmektedir.

Tarım
•Tarım Reformu Genel Müdürlüğü
•Toprak Koruma ve Arazi Kullanımı Kanunu
Orman
•Tarım ve Orman Bakanlığı
•Orman Kanunu
Mera
-Tarım ve Orman Bakanlığı
•Mera Kanunu
Tescil Harici
-Mal Sahibi Idare
•Kamulaştırma Kanunu
Hazine/Devletin H.T.A.
•Milli Emlak Genel Müdürlüğü
•Elektrik Piyasası Kanunu

Şekil 8. Arazi sınıfına göre ENH kamulaştırma sürecindeki kurum ve kanunlar

ENH projesi için kamulaştrrlacak ve irtifak hakkı tesis edilecek taşınmazlara ödenecek bedeli tespit etmek amacıyla TEDAŞ bünyesinde üç kişiden oluşan bir kıymet takdir komisyonu görevlendirilir. Kamulaştırma Kanunu'nun 8.maddesine göre oluşturulan bu komisyon uzman kişi, kurum ya da kuruluşlardan varsa ticaret odalarından ve mahalli emlak bürolarından rapor veya bilgi alarak taşınmaz değerleme çalışmasının altyapısını oluşturur. Daha sonra, Kamulaştırma Kanunu'nun 11.maddesinde belirtilen kriterleri dikkate alarak kamulaştırılacak taşınmazların değerlerini belirleyen bir rapor komisyon tarafından hazırlanır. Raporda dikkate alınan değer kriterleri taşınmazın cinsi, yüzölçümü, kıymetine etki edebilecek nitelikleri, vergi beyanı, daha önce yapılmış kıymet takdirleri, net geliri, arsalarda emsal satış değeri, yapılarda birim fiyatları ve maliyetleri kapsamaktadır.

ENH projesinde pilon yerleri için kısmi kamulaştırma söz konusudur. Parsellerin kamulaştırmaya girmeyecek kısımlarında kamulaştırma nedeniyle bir değer değişikliği olmayacağı değerlendirmiștir. Bu nedenle, direk yerleri için kamulaştırma bedelleri, takdir edilen parsel değerinin kamulaștırmaya düșen kısmı üzerinden hesaplanmıştır. ENH'nın üzerinden geçtiği parseller için ise taşınmaz mülkiyetinin kamulaştırılması yerine kamulaştırma yoluyla irtifak hakkı kurumaktadır. Bu aşamada da kıymet takdir komisyonun belirlediği irtifak hakkı kamulaştırma bedelleri esas alınır.

Kıymet takdir çalışmalarının ardından TEDAȘ bünyesinde kurulan Uzlaşma Komisyonu ile taşınmaz malikleri arasında uzlaşma görüşmelerinin yapılabilmesi için maliklerin Mekânsal Gayrimenkul Sisteminde (MEGSIS) kayıtlı adreslerine Pazarlığa Çağrı Bildirimleri (PÇB) gönderilir. PÇB'de taşınmazla ilgili bilgiler, taşınmazın kamulaştırılacak yüzölçümü, uzlaşma görüşmelerinin yer ve tarihine ilişkin bilgiler bulunmakta, kamulaștırma bedeline ilişkin bilgi ise bulunmamaktadır. Ayrıca, uzlașma görüşmelerine katılım sağlanmaması durumunda ilgili kanuna göre işlem yapılacağı belirtilir. Bu aşamada, ölü kişiler adına kayıtlı taşınmazlar, yetersiz adres, tebligatın ulaşmaması gibi durumlar için ilave çalışma yapılması gerekmektedir. $\mathrm{Bu}$ çalışmalar kamulaștırmayı yapan idare personeli tarafından yürütülmekte olup aracı, avukat veya baş̧ka kişilerin görevlendirilmesi söz konusu olmamaktadır.

Uzlaşma görüşmeleri sonucunda uzlaşmaya varılan taşınmazlar için taşınamaz sahibi ve uzlaşma komisyonu üyelerinin imzaladığı satın alma tutanağı hazırlanır. Bu tutanak tescil işleminin hukuki dayanağını oluşturacağından ilgili taşınmaz, malik ve ödenecek bedele ilişkin ayrıntılı bilgi içermektedir. Uzlaşma sağlanan taşınmazlar için hazırlanan tutanaklar tescil işlemleri yapılmak üzere Tapu Sicil Müdürlüğü'ne gönderilir. Uzlaşılamayan durumlarda anlaşmazlık tutanağı düzenlenerek taraflarca imzalanır. Ayrıca, tebligat ulaşıp görüşmeye katılmayan veya görüşmeye katılıp anlaşmazlık tutanağını imzalamayan taşınmaz sahipleri için imtina tutanağı düzenlenir. Uzlaşma sağlanamayan taşınmazlar için kamulaştırmayı yapan idare taşınmazın bulunduğu yerin bağlı olduğu Asliye Hukuk Mahkemesi'ne müracaat ederek kamulaştırmaya yönelik bedel tespitini ve taşınmazların idare adına tescilini talep eder. Söğütlü-Sancaktepe ENH projesinde parsellerin \%36'sı için anlaşma/uzlaşma sağlanmiştır.

Uzlaşma oranının düşük olmasının temel nedeni taşınmaz için takdir edilen bedelin malikler tarafından yeterli bulunmamasıdır. Türkiye'de taşınmaz değerlemede yaşanan sorun büyük oranda taşınmazların güncel alım satım değerleriyle taşınmaz özelliklerini bir arada yönetebilecek bir 
altyapının olmamasından kaynaklanmaktadır. Bunun yanında, taşınmaz değerlemenin uluslararası standartları benimsenmediğinden bir tașınmazın farklı uygulamalar için (kamulaştırma, alım-satım, vergilendirme gibi) farklı değerleri ortaya çlkabilmektedir.

\section{BULGULAR VE TARTIŞMA}

Sadece ENH projeleri için değil, genel olarak Türkiye'deki kamulaştırma çalışmaları hazırlık aşamasında karşılaşılan en büyük problem mevcut kadastro verilerinin kalitesiyle ilgilidir. Kadastro Kanunu'nun 22-a maddesine göre kadastro yenile çalışması yapılmamış proje alanlarında geçmişte farklı standartlarda üretilen kadastro haritaları günümüz ihtiyaçlarını karşılamaktan uzaktır (Döner, 2015). Farklı ölçme teknikleriyle, farklı koordinat sitemlerinde ve farklı doğruluklara sahip olarak üretilmiş olan kadastro haritaları çeşitli ölçü, tersimat ve yüzölçümü hesap hatalarıyla yüklü olduklarından kamulaştırma çalışmalarında kullanılmaları zorlaşmaktadır (İşcan ve Vargeloğlu, 2019; Alkan, 2019). Teknik problemlerden diğeri de, proje sonrası özellikle tarım arazilerinin parsel boyutlarının verimli üretime imkân vermeyecek şekilde değişikliğe uğramasıdır (Boztoprak, 215; Boztoprak vd., 2016).

Kamulaştırmanın izin/tahsis işlemleri sonraya bırakılarak devam ettirildiği bir süreç Kamulaştırma Kanunu'nun 27.maddesi dayanak alınarak mümkündür. Kanunda acele kamulaştırma olarak adlandırılan bu yönteme yurt savunması ihtiyacının gerekli kılması, aceleliğine Cumhurbaşkanınca karar alınacak hallerin bulunması ve özel kanunlarla öngörülen olağanüstü durumların olması halinde başvurulabilir. Acele kamulaştırma yapılması durumunda, doğrudan taşınmaz değerleme aşamasına geçilmektedir. Projelerin hayata geçirilmesini hızlandırmakla birlikte, Anayasa ile güvence altına alınmış mülkiyet hakkının sıklıkla bu şekilde kısıtlanmasının hukuka olan güveni zedelediği, toplum tepkisine neden olduğu, Anayasa Mahkemesi ve Avrupa İnsan Hakları Mahkemesine yapılan başvuruları artırdığı birçok çalışmada ifade edilmiştir (Göztepe, 2017; Çakır, 2019; Kuru, 2019; Mamal, 2019).

İdeal çözüm kadastronun tașınmaz değerlemeyi de içerek şekilde yeniden modellenerek bir arazi idaresi sistemi halini almasıdır. Türkiye'de bu yönde adımlar da atılmaktadır. 4 Şubat 2019 tarih ve 30677 sayılı Resmî Gazete'de yayımlanan 30 numaralı Cumhurbaşkanlığı Kararnamesìnin 16-23 maddeleri uyarınca yapılan yasal düzenleme ile Tapu ve Kadastro Genel Müdürlüğü (TKGM) bünyesinde Taşınmaz Değerlemesi Daire Başkanlığı kurulmuştur (RG, 2019a). Düzenlemeyle TKGM'ne taşınmazların toplu değerleme yöntemleriyle değerini belirleme, değer bilgi merkezini kurma, yönetme ve değer haritalarının üretilmesi ile güncel tutulmasını sağlama görevi verilmiștir. Ayrıca, 7
Kasım 2019'da ulusal konumsal veri altyapısına ilişkin hedef ve stratejini oluşturulması, kurumlar arası koordinasyonun sağlanması, ulusal veya uluslararası standartlara uygun olarak hazırlanacak coğrafi veri temalarının güncellenmesi amacıyla bir Cumhurbaşkanlığı Kararnamesi yayınlanmıştır (RG, 2019b). Toplam 32 coğrafi veri temasının listelendiği kararnamede Kadastro Veri Teması (KVT) da bulunmaktadır. KVT ilk olarak 2012 yılında Coğrafi Bilgi Sistemleri Genel Müdürlüğü tarafından bir ISO standardı olan ISO 19152 LADM (Land Admininstration Domain Model-Arazi İdaresi Temel Modeli) ile uyumlu olarak hazırlanmıştır (Döner ve Biyık, 2013).

Arazi idaresi alanındaki bilgileri modellemek için 2012 yılında ISO standardı olarak kabul edilen LADM, 2022 yılında taşınmaz değerlemeyi de modelleyecek şekilde güncellenecektir (Kalogiannia vd., baskıda; Kara vd., baskıda). Türkiye'deki kadastro veri temasinın da buna uygun olarak güncellenmesi gelecekte taşınmazların değer bilgilerinin kadastro verileriyle birlikte kullanılabilmesi ve uluslararası standartların benimsenmesi açısından önemlidir. Alternatif bir çözüm olarak daha önce yapılmış taşınmaz değer takdirlerinin tutulduğu bir veritabanın olușturulması ve kıymet takdiri sırasında bu veritabanın kullanılması önerilebilir (Bakan, 2019).

\section{SONUÇLAR}

ENH projeleri hazırlanırken başta ekonomik, çevresel ve güvenlik gibi konular dikkate alınarak ENH'nın geçirileceği araziler belirlenmektedir. ENH projelerinin hayata geçirilebilmesi belirlenen bu arazilerin mülkiyetinin kazanılması süreci sonrasında mümkün olmaktadır. Arazi mülkiyetinin kazanılması sürecinde yaşanan problemler ENH projelerinin uygulanmasında gecikmelere, dava sayılarının artmasına ve kamuoyu tepkisine yol açmaktadır. $\mathrm{Bu}$ çalışmada, ENH projelerinin uygulanmasında arazi mülkiyetinin kazanılması süreci örnek bir proje üzerinden değerlendirilmiştir. TEDAȘ tarafından gerçekleştirilen ENH projelerinde beş yıllık dönem için maliklerle mahkemesiz uzlaşma oranı \%13'dür. ENH için arazi mülkiyetin kazanılmasında en büyük problem taşınmaz değerleme faaliyetlerinden kaynaklanmaktadır. Taşınmaz değerlemede kurumlardaki personel sayısı yetersizliği, taşınmazların güncel alım-satım değerlerine ulaşamama ve bir standart birliğinin sağlanamaması sonucunda, belirlenen arazi değeri çoğu durumda gerçek değeri yansıtmadığından arazi sahipleriyle uzlaşma olmamaktadır. En ideal çözümün yasal boyutta, taşınmaz değerleme faaliyetlerini tek başına düzenleyen bütüncül bir değerleme yasasının hazırlanması, kurumsal boyutta kadastronun taşınmaz değerlemeyi de içermesi ve teknik boyutta güncel alım-satım değerleriyle birlikte taşınmaz özelliklerinin bir arada yönetilebileceği bir veri tabanının 
oluşturulması olduğu değerlendirilmektedir. Bunun yanında, klymet takdiri sırasında mahkeme kararlariyla kesinleşmiş bedeller üzerinden taşınmaz bedelinin belirlenmesi taşınmaz değerlemeyle ilgili problemlerin çözümüne katkı sağlayacaktır. Kadastro altlıklarının yetersiz olduğu yerlerde öncelikle kadastro yenilemenin yapılması karşılaşılan teknik problemleri azaltacaktır. Ayrıca, Anayasa güvencesi altındaki mülkiyet hakkına müdahale edilirken adaletli bir yaklaşım benimsenmeli, kamu yararı yanında taşınmaz sahiplerinin hayatlarını sürdürmek için ihtiyaç duydukları mülkleri de korumayı hedefleyen dengeli bir çözümün araştırılması gerekmektedir.

\section{BILGGILENDİRME/TEŞEKKÜR}

TEDAȘ-ARAS Bölge Müdürlüğü'ne bilgi ve belge sağlayarak çalışmaya katkıları için teşekkür ederiz.

\section{ARAŞTIRMACILARIN KATKI ORANI}

Fatih Döner: Veri toplama, Araştırma, Makale yazma, Düzenleme; Erhan Kaya: Veri toplama, Düzenleme

\section{ÇATIŞMA BEYANI}

Herhangi bir çıkar çatışması bulunmamaktadır.

\section{KAYNAKÇA}

Alkan, U. (2019). Karayolları kamulaștırmasında karşılaşılan sorunlar ve çözüm önerileri. Yüksek Lisans Tezi. Karadeniz Teknik Üniversitesi Fen Bilimleri Enstitüsü, Trabzon.

Bakan, D. (2019). Karayolları kamulaştırmasında değerleme sürecinin incelenmesi. Yüksek Lisans Tezi. Karadeniz Teknik Üniversitesi Fen Bilimleri Enstitüsü, Trabzon.

Başlak, A. (2013). Çok kriterli karar verme tekniği kullanarak enerji nakil hattı $(\mathrm{ENH})$ güzergâh seçimi. Yüksek Lisans Tezi. Selçuk Üniversitesi Fen Bilimleri Enstitüsü, Konya.

Bayındır, B. (2018). Enerji Nakil Hattı Kamulaștırmalarında; Değer Tespiti ve Karşılaşılan Sorunlar, Yüksek Lisans Tezi, Selçuk Üniversitesi Fen Bilimleri Enstitüsü, Konya.

Boztoprak, T. (2015). Kamulaştırmanın parsel sayısı ve ortalama parsel büyüklügüne etkisi. S.Ü. Müh. Bilim ve Tekn. Derg., 3(2), 10-17.

Boztoprak, T., Demir, O. ve Çoruhlu, Y.E. (2016). Comparison of expropriation and land consolidation on the regulation of agricultural land. Sigma J Eng \& Nat Sci, 34(1), 43-55.

Çağla H., İşcan, F. ve Hekim, B. (2016). Kamulaştırma kanunun 27.madde uygulaması (Acele Kamulaştırma). Selçuk Üniversitesi,
Teknik Eğitim Fakültesi, Teknik-Online Dergi, 15 (1), 23.

Çakır, Y. (2019). Kamulaștırmasız el atmanın mülkiyet hakkı bakımından anayasal incelenmesi. Yüksek Lisans Tezi. İstanbul Sabahattin Zaim Üniversitesi Sosyal Bilimler Enstitüsü, İstanbul.

Çelik, D. ve Baz, İ. (2019). Kurumların açtığı kamulaştırma bedel tespit dosyalarına ilişkin bir inceleme. İstanbul Ticaret Üniversitesi Teknoloji ve Uygulamalı Bilimler Dergisi, 1(2), 63-69.

Döner, F. (2015). Evaluation of cadastre renovation studies in Turkey, Survey Review, 47(341) 141-152.

Döner, F. ve Bıyık, C. (2013). Conformity of LADM for modeling 3D/4D cadastre situations in Turkey. In Proceedings of The 5th Land Administration Domain Model Workshop, 2425 September 2013, Kuala Lumpur, Malaysia.

Erdem, N. (2019). Türkiye taşınmaz değerleme sisteminin etkinliğinin araștırılması. Geomatik Dergisi, 4(1), 1-13.

Eroğlu, H. (2014). Coğrafi bilgi sistemleri, kullanılarak gerçekleştirilecek olan bilgisayar destekli bir modelle elektrik enerji nakil hatlarının güzergâh optimizasyonu, Doktora Tezi. Selçuk Üniversitesi Fen Bilimleri Enstitüsü, Konya.

Göztepe, Ö. (2017). Tarihsel kapitalizmin yapısal unsuru ilkel birikim ve bir araç olarak Türkiye'de acele kamulaştırma. Doktora Tezi. Akdeniz Üniversitesi Sosyal Bilimler Enstitüsü, Antalya.

İşcan, F. ve Vargeloğlu, F. (2019). Boru hattı kamulaştırma çalışmalarında karşılaşılan teknik, ekonomik, hukuki sorunlar ve çözüm önerileri. Geomatik Dergisi, 4(3), 239-253.

Kalogiannia, E., Dimopoulou, E., Thompson, R. J., Lemmen, C., Ying, S. ve van Oosterom, P. (baskıda). Development of 3D spatial profiles to support the full lifecycle of 3D objects. Land Use

Policy, https://doi.org/10.1016/j.landusepol.2019.10 4177.

Kara, A., van Oosterom, P., Cağdaş, V., Işıkdağ, Ü. ve Lemmen, C. (baskıda). 3 Dimensional data research for property valuation in the context of the LADM Valuation Information Model. Land Use Policy, https://doi.org/10.1016/j.landusepol.2019.10 4179.

Kuru, İ. (2019). Mülkiyet hakkı kapsamında kamulaştırma bedelinin tespiti ve tescil davaları. Yüksek Lisans Tezi. Çağ Üniversitesi Sosyal Bilimler Enstitüsü, Mersin.

Mamal, M. (2019). Kamulaştırmasız el atmada tazminat ve ecrimisil. Yüksek Lisans Tezi. Ondokuz Mayıs Üniversitesi Sosyal Bilimler Enstitüsü, Samsun.

Marabaoğlu, S. N. ve Uzun, B. (2019). Yüksek voltajlı iletim hatları ve taşınmaz değeri. TMMOB 
Harita ve Kadastro Mühendisleri Odası, 17. Türkiye Harita Bilimsel ve Teknik Kurultayı, 25-27 Nisan 2019, Ankara.

RG (Resmi Gazete), 2001. 08.12.2001 tarih ve 24607 Sayılı Resmi Gazete'de yayımlanan Türk Medeni Kanunu, (Erişim Tarihi:18.06.2020) https://www.resmigazete.gov.tr/eskiler/2001 /12/20011208.htm.

RG (Resmi Gazete), 2019a. 30 Numaralı Cumhurbaşkanlığı Kararnamesi, (Erişim Tarihi: 03.05.2020)

https://www.resmigazete.gov.tr/eskiler/2019 /02/20190205-7.pdf.

RG (Resmi Gazete), 2019b. Coğrafi Bilgi Sistemleri Hakkında Cumhurbaşkanlığı Kararnamesi, (Erişim Tarihi: 03.05.2020), https://www.mevzuat.gov.tr/MevzuatMetin/1 9.5.49.pdf.

Şenyıldız, Z. (2017). Türkiye için taşınmaz değerlemesine yönelik bütüncül bir yönetim modelinin tasarlanması. Yüksek Lisans Tezi. İstanbul Teknik Üniversitesi Fen Bilimleri Enstitüsü, İstanbul.

Tanrıvermiş, H. ve Aliefendioğlu, Y. (2019). Türkiye'de gayrimenkul ve varlık değerleme çalışmalarının gelişimi ve kurumsallaşma eğilimlerinin değerlendirilmesi. Kent, İnşaat ve Ekonomi Kongresi, 2-3-4 Mayis 2019, Gaziantep.

TEDAȘ, (2018). TEDAŞ 2018 yılı faaliyet raporu: https://www.tedas.gov.tr/sx.web.docs/tedas/ docs/faaliyetrapor//FAALIYET_RAPORU_2018 _Tr.pdf.

TEİAȘ, (2020a). Türkiye elektrik üretim istatistikleri:

https://webapi.teias.gov.tr/file/428bcf3cd041-4c7b-95b0-aac1ef80d2a8?download.

TEİAŞ, (2020b). Türkiye iletim hat uzunluklarının yillık gelişimi: https://webapi.teias.gov.tr/file/3cdbf09228d1-4920-8a37-691607e4e01f?download.

Ünel, F. ve Yalpır, Ş. (2019). Türkiye'de taşınmazların değerini etkileyen kriterlere yaklaşım. Geomatik Dergisi, 4(2), 112-133.

Yildirim V., Yomralioğlu T., Nişanci R., Çolak H.E., Bediroğlu Ş. ve Memişoğlu T. (2016). An integrated spatial method for minimizing environmental damage of transmission pipelines. Polish Journal of Environmental Studies, 25, 2563-2653. 